\title{
Legal Culture in Border Areas (Study in Ketungau Hulu and Ketungau Tengah Subdistricts, Sintang District, West Kalimantan Province)
}

\author{
Robert Hoffman ${ }^{1}$, Budiman Ginting ${ }^{2}$, Kamarullah $^{3}$, Mirza Nasution ${ }^{4}$ \\ \{tobing_unka@yahoo.com ${ }^{1}$, budiman.gt59@gmail.com², kamarullah.uun@gmail.com³ \\ mirzanasution72@gmail.com $\left.{ }^{4}\right\}$ \\ Universitas Sumatera Utara, Indonesia ${ }^{1,2,4}$ \\ Universitas Tanjungpura, Indonesia ${ }^{3}$
}

\begin{abstract}
The statutory regulation governing the border areas of Indonesia is Law Number 43 of 2008 concerning State Territory (State Gazette of the Republic of Indonesia of 2008 Number 177 and Supplement to State Gazette of the Republic of Indonesia Number 4925). The purpose of this paper is to determine and analyze the legal culture of the communities surrounding the border areas of the country. The theory used in this study is the Legal System theory from Lawrence M. Friedman which says that legal culture is defined as a number of ideas, values, expectations and attitudes towards law and legal institutions, some of which are public or some are in the public domain. This study uses a normative juridical research method using a statutory approach with a descriptive analytical research nature, which provides an overview of the legal culture of the community around the border area. This study analyzed the data obtained, then systematically compiled and analyzed the data qualitatively to clarify the problem being discussed. The legal culture of the communities surrounding the border of Indonesia and Malaysia, specifically in various villages in Ketungau Hulu and Ketungau Tengah Subdistricts, Sintang District, West Kalimantan Province is below standards. Due to a lack of publication of statutory regulations, these communities show little regard to the law. They only see the law as the police, soldiers, and other officials in uniform. The information must be published by all responsible parties, namely the central, regional, and village governments and the community through various means of communication, information, socialization, or other forms of means or media.
\end{abstract}

Keywords: Legal Culture, Territory, Border, Country

\section{Introduction}

Indonesia adheres to a Civil Law System which prioritizes laws and regulations. Therefore, the Indonesian borders are also managed according to laws and regulations. The regulation that governs the borders of Indonesia is Law Number 43 of 2008 concerning State Territory (State Gazette of the Republic of Indonesia of 2008 Number 177 and Supplement to State Gazette of the Republic of Indonesia Number 4925). The law consists of 12 chapters, 26 articles, and explanatory sections which were passed by the President on November 14, 2008.

The existence of Law Number 43 of 2008 concerning State Territory is to ensure that there will be no discord in the border which can affect the attitudes and actions of citizens in protecting the territory of the country [1]. The borders of Indonesia need to be strictly regulated considering 
that there are multiple border areas. The main ideas contained in Law Number 43 of 2008 concerning State Territory are [1]:

a. The territory of the state, namely land, inland, archipelagic and territorial waters, the seabed and the land underneath, as well as the skies above, including the resources contained therein.

b. Sovereign rights of the Republic of Indonesia in the exclusive economic zone and the continental shelf as well as supervisory rights in additional zones.

c. The government's authority to regulate the management and utilization of state territory and border areas.

d. Institutions authorized to manage border areas.

This regulation is intended to provide legal certainty regarding the scope of the state territory, the authority to manage state territory, and sovereign rights [2].

To successfully manage state borders, a legal culture needs to be established for the surrounding communities. This must be prioritized by all related parties to ensure justice and prosperity for the people and the nation.

Friedman [3] states that law is a combination of legal substance, structure, and culture. The legal substance is the output of the legal system in the form of regulations and decisions that are used by both the regulators and the regulated. The legal structure is the institutions created by the legal system that contain various functions to support the operation of the system. Legal culture consists of values and behaviors that affect the enforcement of the law which are, according to Ali [4] the social mindset and forces that determine how the law is used, avoided, or abused. Friedman defines legal culture as a collection of ideas, values, expectations, and behavior towards the law and legal institutions, some of which are public or in the public domain [5]. The purpose of this paper is to determine and analyze the legal culture of the communities surrounding the border areas of the country.

\section{Research Method}

This is normative juridical research using a statutory approach with the nature of descriptive analysis research, which is to provide an overview of the legal culture of the surrounding communities of border areas. This research qualitatively analyzes the data, then systematically arranges and qualitatively analyzes the data to clarify the issues being discussed.

\section{Results and Discussion}

\subsection{Legal Culture in Border Areas}

Territorial boundaries on land are the boundaries agreed upon by the Dutch East Indies Government and the British Government in Kalimantan and Papua, and the Portuguese Government on Timor Island which subsequently became Indonesian territory based on the principle of uti possidetis juris applicable in international law. Based on this principle, an independent country inherits the territory of its former colonial state.

The land boundary between Indonesia and Malaysia was established on the basis of the Dutch East Indies and British Indies Conventions of 1891, 1915, and 1928. The land boundary 
between Indonesia and Timor Leste was determined on the basis of the Convention on the Delimitation of the Boundaries of the Dutch East Indies and Portugal in 1904 and the decision of the Permanent Court of Arbitration (PCA) 1914. The land boundary between Indonesia and Papua New Guinea was established on the basis of the 1895 Dutch-British Indies Boundary Treaty.

The boundaries of the Indonesian state on land bordering Malaysia are in the Provinces of West Kalimantan, East Kalimantan Province, and North Kalimantan Province. In particular, West Kalimantan Province has a land border area which is spread over 5 (five) regencies, namely: Sanggau, Sambas, Sintang, Kapuas Hulu, and Bengkayang. The land border line in West Kalimantan Province along 966 Kilometers separates the territory of the Republic of Indonesia from the territory of Sarawak, Malaysia.

Sintang District, West Kalimantan Province, is a district that is directly adjacent to East Malaysia, with the administrative boundaries being: a) North: Kapuas Hulu District and Malaysia; b) South: Melawi District, Central Kalimantan Province; c) East: Kapuas Hulu District; d) West: Sekadau District, Sanggau District, and Melawi District.

The border area of Sintang District covers $4,306 \mathrm{~km}^{2}$, consisting of 58 villages and 186 hamlets. Sintang has 2 subdistricts that are directly adjacent to Malaysia, namely Ketungau Hulu and Ketungau Tengah. The two sub-districts are sub-districts that are directly adjacent to the State of Malaysia, precisely in the Sri Aman District, a sub-district located in the State of Sarawak, East Malaysia. The population in the two sub-districts in 2019 reached a total of 53,691 people, respectively 22,532 people in Ketungau Hulu District and 31,159 people in Central Ketungau District.

According to the government structure in Indonesia, border areas are managed by village governments within the subdistrict. There are several villages in Ketungau Hulu and Ketungau Tengah subdistricts, Sintang, West Kalimantan which are directly adjacent to the Malaysia, namely: Sungai Kelik, Jasa, Nanga Bayan, Sungai Seria, Senaning, Rasau, Muakan Petinggi, Sebuluh, Riam Sejawak, Engkeruh, and Neraci Jaya.

These villages are home to traditional communities. Villagers rely on agricultural and forest products that are sold to Malaysia as the closest destination with higher selling prices compared to Indonesia.

Customary law and leaders govern these villagers; they are more prevalent than state laws and regional regulations. Even village regulations as legal products are sparsely found.

Further attention is required to improve the conditions of these villages, as the facilities and infrastructure are generally inadequate.

Residents in these two sub-districts are still often in and out of Malaysia. The goal is not to picnic, travel or travel, but solely to meet their needs. There are several factors that cause residents to often go in and out of Malaysia, including:

a. The distance to Malaysia is closer when compared to Sintang City, as the capital of Sintang Regency. The distance from Senaning, the capital of Ketungau Hulu sub-district to Sintang City is about $189 \mathrm{~km}$, while to Sri Aman, Malaysia it is about $156.8 \mathrm{~km}$. Meanwhile, the distance from Nanga Merakai, the capital of Central Ketungau District to Sintang City is about $99 \mathrm{~km}$, while to Sri Aman, Malaysia it is $78.3 \mathrm{~km}$.

b. Prices of basic commodities in Sri Aman, Malaysia are cheaper.

Population traffic to neighboring Malaysia is not a desire but a necessity, because conditions in their area (Ketungau Hulu and Ketungau Tengah sub-districts) still lack facilities and infrastructure or public facilities in all fields, such as roads, electricity, educational facilities, health. , market, and so on. 
The limited conditions finally made the residents look for a way out to venture across to neighboring Malaysia even though they had to walk through jungles and hills or river paths. There is no official border route as an entry point between Indonesia and Malaysia, so the border routes that are often used by residents of the two countries to enter and leave are strictly guarded by the military of each country, Indonesia and Malaysia with the establishment of the Border Security Post (Pos Pamtas) to protect the boundaries of their respective countries.

Residents in the two sub-districts view that neighboring Malaysia provides a lot of their necessities of life, so they often go in and out of Malaysia. So, they travel to Malaysia not for tours or picnics but to survive by selling agricultural and plantation products, shopping to meet household needs and medical treatment when sick. Residents in Ketungau Hulu and Ketungau Tengah sub-districts want their area to be developed that provides various facilities and infrastructure for their survival. This then raises the author's sad attitude towards the fate of the Indonesian population living in the border areas of the country who have not yet enjoyed the comfort of life when the State of Indonesia has entered the age of 75 years of independence.

Seeing the life of the people in the border areas of the country which is still a concern, the sub-districts which are part of the district/city area as their place of residence must of course be managed as well as possible. The management of sub-districts located in state border areas must be carried out with clear arrangements which include authority, budget and so on.

In addition, the legal culture of these villages raises concerns. The community is rather disobedient to the law. There are still many cases of illicit trafficking between Indonesia and Malaysia. Many people in border areas still do not know and understand the laws and regulations in Indonesia due to the lack of publication of statutory regulations in the region.

It is highly important to publish statutory regulations as Indonesia is a state of law. One of the principles of a legal state is the principle of legality; the actions of the government and all its citizens must be based on the prevailing laws and regulations. Gautama [6] stated that there are 3 (three) characteristics or elements of a legal state, one of which being the principle of legality: "Every state action must be based on the law which must also be obeyed by the government and its apparatus". Ten Berge [7] states that the principle of legality is one of the principles of a legal state: "The limitation on the freedom of citizens (by the government) must be based on laws as general regulations".

The legal state of Indonesia also adheres to the principle of legality as stated by Prodjodikoro [7]: "in acting towards citizens and among each other, all state organs, especially governmental organs cannot act carelessly; they must adhere to the law. All social relations must comply with the applicable legal regulations". From the explanation of the experts above, it can be concluded that a legal state contains the principle of legality.

As a constitutional state, Indonesia possesses written law as stated in Law Number 12 of 2011 concerning the Formation of Laws and Regulations amended by Law Number 15 of 2019 , which includes: 1) The 1945 Constitution of the Republic of Indonesia; 2) The People's Consultative Assembly Decrees; 3) Laws/Government Regulations in Lieu of Laws; 4) Government Regulations; 5) Presidential Regulation; 6) Provincial Regulations; and 7) District/City Regulations.

Other laws and regulations include the regulations stipulated by the People's Consultative Assembly, the People's Representative Council, the Regional Representative Council, the Supreme Court, the Constitutional Court, the Supreme Audit Agency, the Judicial Commission, Bank of Indonesia, Ministers, agencies, institutions, or commissions of the same level which is formed by law or the government at the behest of the law, the Provincial People's Representative Council, the Governor, the Regency/City People's Representative Council, the Regent/Mayor, the Village Head, or its equivalent. The existence of these laws and regulations is recognized 
and has binding legal force as long as it is ordered by higher laws and regulations or is established based on authority ${ }^{1}$.

In the science of legislation, the publication of laws and regulations is one of the principles of statutory regulations, namely: the principle of "het beginsel van de kenbaarheid" (recognizable). Attamimi [8] states that this principle is one of the principles that define a good law and/or regulation in the Netherlands: "If a law or regulation is not recognized and known by the general public, especially by higher-ups and officials, then it will lose its purpose. It fails to enact the principle of equality and the principle of legal certainty, thus failing to enact the regulation itself. This principle is very much needed, especially if the laws and regulations impose the people with various obligations. The principle which states that the general public is considered to understand the laws and regulations needs to be balanced with this principle" [8]. Fuller [3] said that the regulations that have been issued must be published, so Twining's [9] "ex-cathedra" statement of the law applied equally in society is very accurate indeed.

The principle of publication is different from the principle of promulgation. The principle of promulgation assumes the general public knows the laws and regulations. This principle is commonly known as the theory of legal fiction or commonly known as the theory of prejudice [10]. In her work, Soeprapto [11] considers the term "promulgation" to be different from "announcement" (in her writing, the publication is part of the "announcement"). According to her, in the Dutch language, promulgation is translated to "Afkondiging" while the announcement is translated to "Publicatie". The definition of each is as follows [11]:

a. Afkondiging (Promulgation): ter openbare bekendmaking, voor orderscheidene overheidshandelingen voorgeschreven en wel veal op strafe van nietigheid (public announcement regarding government actions, partly with criminal sanctions).

b. Publicatie (Announcement/Publication): bekendmaking, openbaarmaking (announcement, disclosing information to the public).

c. Promulgation: The order given to cause a law to be executed and published; it differs from publication.

d. Publication: To make public, to make known to people in general; to bring before public.

According to Soeprapto [11]: "promulgation is a formal announcement of state regulation through a special official publication following the applicable provisions. Through this, the regulation has fulfilled the principle of formal notification, fulfilled the requirements to be a regulation, fulfilled the formation procedure, and has been recognized (kenbaar) which gives it binding power. The purpose of promulgation is to ensure that the general public formally recognizes state regulations (een ieder wordt geacht de wet te kennen) so that there is no excuse for not knowing them (opdat niemand hiervan onwetendheid voorwende), and ignorance of these regulations does not make a person subject to pardon (ignorantia iuris neminem excusat).

Promulgation is necessary to ensure that the general public formally recognizes state regulations (een ieder wordt geacht de wet te kennen) and ignorance of these regulations does not make a person subject to pardon (ignorantia iuris neminem excusa) [11]. The publication is a material announcement of a law or regulation to the public with the main objective of making the contents of the law or regulation as widely known as possible. Laws and regulations can be published in various ways, through dissemination, issuance, and many others. The purpose of a publication is to make the public as much as possible materially aware of the laws and regulations and understand the contents and purposes contained therein [11].

${ }^{1}$ See Article 7 Paragraph (1) and Article 8 Paragraphs (1) and (2) Law Number 12 of 2011 concerning the Formation of Laws and Regulations. 
From Maria Farida Indrati Soeprapto's statement, it can be said that the concept of promulgation contains the principle: "the general public is assumed to know the laws and regulations" or also known as the theory of legal fiction in law science. Meanwhile, the concept of the publication contains the principle: "the general public knows the laws and regulations". In addition, Soimin's [12] work defined promulgation: "Promulgation is the sole condition for binding power". Binding power is the basis of validity. From this, the theory of legal fiction which states that "the general public is assumed to know the laws and regulations" emerged. Soimin defines publication as an instrument to ensure that the general public is made aware of the laws and regulations that have been promulgated by both central and regional governments. Whether or not people understand is another matter, as it depends on the implementation of the publication itself. From Soimin's statements above, it can be said that the concept of promulgation contains the principle: "the general public is assumed to know the laws and regulations" or also known as the theory of legal fiction. Meanwhile, the concept of the publication contains the principle: "the general public knows the laws and regulations".

In comparing promulgation and publication, several similarities and differences can be found. Promulgation and publication are similar in that both are required by laws and regulations. The differences can be seen from the principle, characteristic, goal, and time as described below:

Table 1. Comparison of promulgation and publication as seen from the principle, characteristic, goal, and time.

\begin{tabular}{|c|c|c|}
\hline Aspect & Promulgation & Publication \\
\hline Principle & $\begin{array}{l}\text { The general public is assumed to } \\
\text { know the laws and regulations }\end{array}$ & $\begin{array}{l}\text { The general public knows the laws } \\
\text { and regulations }\end{array}$ \\
\hline Characteristics & $\begin{array}{l}\text { An assumption or preconceived } \\
\text { notion that the general public knows } \\
\text { a statutory law. }\end{array}$ & $\begin{array}{l}\text { A fact that applies to the general } \\
\text { public. }\end{array}$ \\
\hline Goal & $\begin{array}{l}\text { To create binding power and the } \\
\text { enactment of laws and regulations. }\end{array}$ & $\begin{array}{l}\text { To ensure obedience to the laws and } \\
\text { regulations that have been } \\
\text { promulgated so that they are } \\
\text { binding and valid. }\end{array}$ \\
\hline Time & $\begin{array}{l}\text { After laws and regulations have been } \\
\text { passed, they will then be } \\
\text { promulgated in an official state } \\
\text { publication. }\end{array}$ & $\begin{array}{l}\text { After laws and regulations have } \\
\text { been promulgated in an official state } \\
\text { publication, it is then published to } \\
\text { the general public. }\end{array}$ \\
\hline
\end{tabular}

From the description above, it can be concluded that the publication of laws and regulations aims to provide knowledge and understanding of a law or regulation.

To provide knowledge and understanding of laws and regulations, publication requires means of communication as according to Soimin [12]: "to know and understand laws and regulations, means of communication are needed". Thoha [13] states that: "communication is a process of delivering and receiving news or information from one person to another". Davis and Newstrom [14] argue that: "communication is the transfer of information and understanding from one person to another. It is a way of conveying ideas, facts, thoughts, and values to others". Meanwhile, Edwin Fillipo as conveyed by Jiwanto [15] defines communication as an act of encouraging other parties to interpret an idea in a way desired by the speaker or writer.

Laws and regulations are information that can be used as a form of communication. According to Davis [16], information is data that has been processed into a form that is important 
to the recipient and has real value that can be felt in current or future decisions. Likewise, Burch and Strater [17] state that information is the collection or processing of data to provide knowledge or information. Meanwhile, Terry [18] defines information as important data that provides useful knowledge.

In the Indonesian constitutional system, information is a human right and thus the right of Indonesian citizens that is guaranteed under Article $28 \mathrm{~F}$ of the 1945 Constitution of the Republic of Indonesia (1945 Constitution), which states that the purpose of obtaining information is to develop character and social environment ${ }^{2}$. The principle of guaranteeing the right to obtain information is under the nature of the Republic of Indonesia as a legal state that upholds human dignity and guarantees the equal position of all citizens in the face of the law, and the desire of the Indonesian people to continuously promote and protect human rights in the life of the people and of the nation. The right to obtain information to develop character and social environment is expressly regulated in Article 14 Paragraph (1) and (2) of Law Number 39 of 1999 concerning Human Rights which states that everyone has the right to communicate and obtain information needed to develop character and social environment and everyone has the right to seek, obtain, own, store, process, and convey information using all available means.

In addition, the right to obtain information is guaranteed in all countries in the world, as stated in Article 19 Paragraph (2) of the International Covenant on Civil and Political Rights, which has been adopted by General Assembly Resolution 2200 A (XXI) of the United Nations on December 16, 1966. Indonesia has ratified this into Law Number 12 of 2005 concerning the Ratification of the International Covenant on Civil and Political Rights. Article 19 Paragraph (2) of the International Covenant on Civil and Political Rights states that everyone has the right to freedom of expression, including the freedom to seek, receive, and impart any information and thoughts, regardless of restrictions in oral, written, or printed forms, through artwork or any other media of choice.

From the explanation above, it is clear that Indonesia as a legal state guarantees all individuals to be able to obtain information and there are no limitations on the information that is sought, obtained, owned, stored, or processed by all individuals. This means that anything can be considered as information, including laws and regulations.

According to Article 1 point 1 of Law Number 14 of 2008 concerning Disclosure of Public Information, information is defined as information, statements, ideas, and signs that contain values, meanings, and messages, data, facts, and explanations that can be seen, listened to, and read which are presented in various digital or analog packages and formats following the development of information and communication technology. Laws and regulations can be considered as public information; according to Article 1 point 2 of Law Number 14 of 2008 concerning Disclosure of Public Information, public information is information that is generated, stored, managed, sent, and/or received by state administration and/or other public bodies following this law and other information related to the public interest.

In the aforementioned article, public bodies are defined as executive, legislative, judicial, and other bodies whose main functions and duties are related to state administration and partly or fully funded by the state/regional budget or non-government organizations as long as some or all of the funds come from the state/regional budget, public donations, and/or foreign countries (Article 1 point 3 ).

Therefore, laws and regulations can be considered as public information that must be published to the general public to ensure public awareness and understanding of the published laws and regulations and the contents and purposes contained therein. Satjipto Rahardjo states

${ }^{2}$ See Article $28 \mathrm{~F}$ of the 1945 Constitution 
that "the general public must know the existing regulations" [19]. Likewise, Ronny Hanintijo Soemitro who quoted Metzger's opinion states that the effectiveness of laws and regulations is determined by the extent to which the general public is aware of the contents contained therein [20].

From the above explanation, the publication of laws and regulations in border areas is very important in the context of realizing a legal culture in which the people know and understand the laws and regulations to create a law-abiding society. The information must be published by all responsible parties, namely the central, regional, village governments, and the community through various means of communication, information, socialization, or other forms of means or media.

\section{Conclusion}

Simply, it can be concluded that the legal culture of the communities surrounding the border of Indonesia and Malaysia in various villages in Ketungau Hulu and Ketungau Tengah subdistricts, Sintang District, West Kalimantan Province require further improvements. The community is rather disobedient to the law. This can be seen in the many cases of illicit trafficking between Indonesia and Malaysia. Many people in border areas still do not know and understand the laws and regulations in Indonesia due to the lack of publication of laws and regulations in the region. The publication of laws and regulations in border areas is very important in the context of realizing a legal culture in which the people know and understand the laws and regulations to create a law-abiding society. The information must be published by all responsible parties, namely the central, regional, village governments, and the community through various means of communication, information, socialization, or other forms of means or media.

\section{References}

[1] H. S. Suryo, “Aspek Hukum Wilayah Negara Indonesia,” Jogyakarta: Graha Media, 2012.

[2] Pemerintah Republik Indonesia, Penjelasan Umum Undang-Undang Nomor 43 Tahun 2008 tentang Wilayah Negara: Alinea ke-6. 2008.

[3] E. Warassih, K. K. Medan, and Mahmutarom, Pranata Hukum: sebuah telaah sosiologis. Suryandaru Utama, 2005.

[4] A. Ali, "Menguak Realitas Hukum," Rampai Kolom dan Artik. Pilihan dalam Bid. Hukum, Kencana Prenada Media Gr. Jakarta, 2008.

[5] P. De Cruz, "Perbandingan Sistem Hukum, Common Law, Civil Law dan Socialist Law," Bandung. Nusa Media, 2010.

[6] D. N. Yunas, Konsepsi Negara Hukum. Angkasa Raya, 1992.

[7] H. R. Ridwan, "Hukum Administrasi Negara: Edisi Revisi," Jakarta PT Raja Graf. Persada, 2011.

[8] A. B. Setiyono, "Pembentukan Peraturan Hukum Daerah yang Demokratis oleh Pemerintah Daerah." program Pasca Sarjana Universitas Diponegoro, 2008.

[9] W. Menski, "Perbandingan hukum dalam konteks global sistem Eropa, Asia dan Afrika." Bandung: Nusa Media, 2016.

[10] A. G. Abdullah, "Pengantar Memahami Undang-Undang Tentang Pembentukan Peraturan Perundang-Undangan,” J. Legis. Indones., vol. 1, no. 2, pp. 1-10, 2018.

[11] M. F. I. Soeprapto and A. H. S. Attamimi, Ilmu Perundang-undangan: Dasar-dasar dan 
pembentukannya. Kanisius, 1998.

[12] Soimin, Pembentukan Peraturan Perundang-Undangan Negara di Indonesia. Yogyakarta: UII Press, 2010.

[13] M. Thoha, "Pembinaan Organisasi: proses diagnosa dan intervensi," 2003.

[14] K. Davis and J. W. Newstrom, "Perilaku dalam organisasi," Jakarta: Erlangga, 1985.

[15] G. Jiwanto, "Komunikasi dalam organisasi," Cet. ke-1. Yogyakarta Pus. Pengemb. Manaj. Fak. Ekon. Univ. Atmajaya, 1985.

[16] G. B. Davis and M. H. Olson, Management information systems: Conceptual foundations, structure, and development. McGraw-Hill, Inc., 1984.

[17] J. G. Burch and F. R. Strader, "Information systems: theory and practice. Santa Barbara." Wiley, 1974.

[18] G. R. Terry, Office Management and Control: The Actions of Administrative Management. Homewood, Ill., Irwin, 1962.

[19] R. Satjipto, "Ilmu Hukum." Cetakan ke-IV, PT. Citra Aditya Bakti, Bandung, 2006.

[20] R. H. Soemitro, Studi hukum dan kemiskinan. Tugu Muda, 1989. 